\title{
EXTERNAL FORCES ON AFRICA'S DEMOCRACY AND DEVELOPMENT
}

\author{
Edward Brenya \\ Kwame Nkrumah University of Science and Technology, \\ Kumasi-Ghana \\ Samuel Adu-Gyamfi \\ Kwame Nkrumah University of Science and Technology, \\ Kumasi-Ghana
}

\begin{abstract}
The argument for Africa's advancement has primarily been discussed on various fronts and amply tied to democracy and development. This notwithstanding, such discourse has neglected the evolutionary process of our political history and development. The need for this review article however, is to reinvigorate the need for African leaders and political actors as well as their foreign counterparts to pay attention to some of the recurrent issues that has stifled the growth of the African continent in particular. In addressing the issues from past to present, attention has been paid to the colonial legacy as well as the question of colonization, history, definition and structure among others.
\end{abstract}

Keywords: Colonization; Democracy; Development; Neo-Colonialism; Aid; Modernization and Dependency. 


\section{Introduction}

For more than four centuries the West has continuously dominated Africa's over 700 million people (Daily Graphic 2002, 7.) Over 2,000 years ago Pliny said, "out of Africa, always something new" (West Africa 2001, 6). Today we get the impression that modern Europe would prefer to say, "Out of Africa, always something bad." There are, of course, plenty of bad things happening in Africa and many of them are entirely the fault of Africans (Okwudiba 1999). But then many of Africa's current problems have their roots in the continent's relations with Europe over the last 300 years and in this regard, unfortunately, the Europeans seem unable to accept with good grace the impact of their imperial control (West Africa 2001, 6).

Nnoli, in the first two chapters of the book, African Public Administration, attributes African problems to colonial inheritance (Okwudiba 1999, 56). The system of public administration in the countries that were colonised by the United Kingdom had its origins in the creation of machinery by Britain, which consolidate her colonial administration in her dependent territories in Africa (Adu 1999, 56). The early service was concerned with pacification of the territories, maintenance of law and order, and collection of revenue. Up to the Second World War, the civil service was hardly concerned with economic and social development. The initiative in the economic and social development came from missionaries, immigrant populations e.g. settlers and ordinary peasants. Missionaries were especially prominent in the provisions of social services such as health and education. The civil service was simple in structure, but was racial in character, reliant on automatic recruitment into senior post from Britain.

Drawing on the case of Cameroon, half of which was administered by the French and the other half by the United Kingdom, Adu offers us a concrete comparison of the two systems of colonial administration. The civil service structure in Francophone Africa, he concludes, was as coarse as its British counterpart was gentle. These differences are attributed to differing social and educational backgrounds of the officers of the two services. It is argued that British recruits could identify themselves with the gentry, while the French were middle class in origin. Also, the two national traditions of the services differed from one another. Britain believed in local rule while France believed in centralisation. On the eve of the Second World War, the two services began to resemble each other (Adu 1999, 68).

It is suggested that the centralizing strategy was heavily influenced by sources outside the continent: the doctrine of elite superiority in consolidating and sustaining the social order; the promises of rationalism, science and money for the transformation of underdeveloped societies; certain interpretations of the experience of continental Europe relating to the emergency of the state, modernisation and bureaucratisation; 
and a heritage of colonial administration which emphasized the executive vis-à-vis other essential political institutions (Adu 1999, 69).

Secondly, it is further suggested that the strategy at independence was carried out through a number of sub-strategies or policies. The most important of these included: (a) replacing competitive politics by one or no party system in the name of "national unity and stability"; (b) forming unified bureaucratic structures exclusively accountable to the central government; (c) undermining the role and significance of local government, including traditional, ethnically related groups as well as modern institutions of true local government; (d) maximization of executive authority at the expense of such other institutions such as the legislature, judiciary, regional governments, press and private organisations; and regarding the national budget as the primary source of funding for the development agenda, and to be raised out of the largest economic sectors: either agriculture or mineral extraction (Adu 1999, 69). Yet to have a better understanding of these issues, there is the need to look at the question of colonization, definitions, history and structure. The others include the impact of colonization on the contemporary Africa's democracy and development, ethnic consciousness and uneven development, neo-colonialism, aid and trade, monopoly and privatization, globalization, modernization as well as dependency theories.

\section{Colonization: Definition, History and Structure}

Two powerful images provide competitive models regarding African precolonial organisation. The first image is one evoked by Pistol in Shakespeare's Henry $I V$ when he opens up with "I speak of Africa and golden joys (Hopkins, 1985, 27). This is the model which also informs Nyerere's depiction of African society. He writes that "people lived together and worked together... the results of their joint effort were divided unequally between them but according to custom... family members thought of themselves as one..." (Nyerere1970, 1). The organizational model evoked by the above image is one characterized by small organizations of equal members living and working together on the basis of clearly understood and totally accepted rules and customs. Of necessity, such organizations were non-hierarchical, based on face-to-face relationships. It is an image of well behaved and motivated organizational members who are peaceful.

If the above image is pretty much in line with the theories of the 18th century French philosopher, Jean Jacques Rousseau, there is another which is very much in line with the ideas of the 18th English political theorist, Thomas Hobbes. This is the image first formed by European explorers and later popularized by European slave traders and masters and later by the colonial state and early scholars of African 
societies, especially anthropologists. The most extreme spoke of the Africa of animals and jungle men; of primitive people "with minds in which the irrational elements predominate" (Mair 1990, 8). The more moderate spoke of stateless societies of people who were primitive but only in their "ways of doing things" (Mair 1990, 8). If natives were constantly at each other in a war of all against all in the extreme viewpoint, the moderates depicted a society characterized by "an apparent anarchy" (Mair 1990, 9). There was, according to this view, an attempt at rule making and enforcement but the rules were fuzzy, covered only a few activities, and were constantly broken.

In search of more empires in order to boast their superiority, the ruling class of the developed capitalist nations extended their domination over the whole world. So by hook or by crook, they seized foreign countries. In Africa, as a follow up of the Berlin Treaty, the whole African continent was carved out and colonized. By political, military, economic and ideological means, the colonialists established their absolute power in the African colonies, ruling them as their subordinate parts of their own metropolitan empires.

It has been argued that the tasks of the colonial state were mainly two. First, it aimed at establishing capitalist relations of production in the African colonies in such a way as to guarantee monopoly or super profits to the capitalists of Europe, particularly of the colonising powers. Secondly, as Okwudiba noted, was to "conquer and subdue the peoples of the African colonies in such a way as to make it easy and cheap to exploit their material and human resources" (Okwudiba 1996, 63). This means that just as the capitalist states in Europe maintained domination over the non-capitalist classes, the colonial powers in Africa exercised domination over the African people as a whole. Similarly, while the European state regulated the operation of the capitalist mode of production in favour or the ruling bourgeois class, it is argued, so also the state in Africa "had first to create the capitalist mode of production, made it dominant in the society and then made it yield super profits for the European capitalists" (Okwudiba 1996, 63).

This, according to Okwudiba's analysis, is the two fold task of the colonial state that defines the character both of the colonial state and the present day Africa (Okwudiba 1996, 63). This analysis focuses more actively and more extensively on the economic, social, cultural and political life of the people of Africa" (Okwudiba 1996, 63). The objective of all this intervention was, of course, to keep the colonial people in such subjugation as to enable the maximum possible exploitation to their labour and resources. And as such, the state power of the colony was designed to maintain this pattern of economic and political control. 


\section{The Impact of Colonization on the Contemporary Africa's Democracy and Development}

It is of certainty that we argue that some of Africa's problems are deeply rooted in the colonial experience. According to Richard Sandbrook, the problem lies in the fact that the "imperial powers failed in various ways to erect a sturdy base for responsive and effective postcolonial states" (Sandbrook 1993, 42). On his part, Okwudiba points out that we cannot isolate the present political, ethnic and economic problems that Africa is facing from the historical condition stemming out from colonialism.

Okwudiba further argues that the type of colonialism that took off during the later part of the nineteenth century was the result of changes which had taken place in the form of "capitalism in the advance capitalist societies" (Okwudiba 1996, 62). For example, the industrial advance in nineteenth-century Europe, the growth of large scale industry, and of concentrations of economic power in the hand of a relatively small number of major companies and banks led to a change in the pattern of relations between the European powers and the countries of Africa, Asia and Latin America inclusive (Okwudiba 1996, 63).

The territories created by imperialism were, in a dual sense, artificial entities, and this has produced severe problems in state building. First, their political style at independence did not evolve organically out of local traditional politics, but rather colonial imperialists imported Western models of state organization into Africa. Colonialism, as it were, was an almost fleeting experience in most of Africa, too transitory to institutionalize alien political structures and norms. Secondly, both the colonies and protectorates were artificial in the sense that the imperialists did not pay attention to cultural and linguistic differences in carving out national boundaries. It is true, as Sandbrook notes, that diverse and sometimes hostile peoples were grouped together within common borders (Sandbrook 1993, 42). These differences were, albeit not intentionally done, by colonial-induced, social, economic and political change. Therefore, Sandbrook concludes that the "legitimacy crisis and ethnic tensions that bedevil postcolonial politics must be understood in the context of the colonial epoch" (Sandbrook 1993, 42).

For the fact that colonial capitalism was not particularly dynamic or creative force also contributed to the contemporary crisis. Imperialism dragged, prodded and enticed Africans into a market economy, but mostly participated only marginally. Economic change was the formation of the modern capitalist class, which gave birth to small bourgeoisie. Considering the external origin of political institutions in Africa may give more insight into the colonial problem of which Africa now faces. Let us 
consider state. Generally, state structures are most likely to win popular support if they evolve organically rather than being imposed from outside. Sandbrook argues that there was hardly any organic link between the political institutions prescribed in constitutions and the indigenous institutions of the pre-colonial period (Sandbrook 1993, 43). Used in the sense of centralized authorities capable of imposing their wish in any territory through an administrative, judicial and coercive apparatus, states, in modern Africa, as a matter of fact, did emerge in pre-colonial Africa (Wickens 1981, 220). One of the necessary conditions for the formation of a state is economic surplus. This existed in pre-colonial Africa, needless to give the full details of the formation of states in pre-colonial period. However, it is, equally important to state that states were financed either through a settled and prosperous agriculture, the proceeds of plunder (which often took the form of slaves or cattle), from revenue derived from long-distant trade. Taxes on imports and exports, precious metals, ivory, slaves or cash were forms of tribute imposed by the rulers to their subjects. The rulers (usually kings and chiefs) in return would provide internal order, defense, protection and regulation of the land, and the construction of public works among other things. Each state comprised different traditions and every state interacted with outsiders freely and friendly.

Essentially Africa evolved a variety of traditional political structures. But, as it is the case, most of the countries created by colonialists contained several traditional societies, each of which valued its own political traditions, myths and symbols. This made state-building very difficult since it was impossible to draw upon a singletraditional model in devising the modern state's institutions. Any government that decides to adopt the indigenous political institutions and traditions of one community above others would face a total declaration of war against the excluded groups, since every group cherishes its way of life.

\section{Ethnic Consciousness and Uneven Development}

The assertion of ethnic identities has in many countries replaced ideological differences as a major source of domestic conflict. Ethnicity is not, of course, a precise concept and those who march under a particular ethnic banner usually have in common a bundle of attributes-a shared history, language, religion and culture and usually also a common racial origin (itself an imprecise term).

Ethnic identities and the clash of ethnic groups are not new of course, but the rise of ethnicity as a political force worldwide is recent, at least in its current form and intensity. Moreover, the end of the Cold War could well mean that the politics of ethnicity will increase in intensity in the years ahead. The same process 
of globalization that has undermined sate power threatens to "unleash subterranean cultural pluralism" (Mitelman 1991, 10). Ethnicity thus poses a challenge to global peace and stability, but the search for a new basis for community and group identity should also be seen as an opportunity-an opportunity for more self-determination, for people to choose the policy under which they live, an opportunity to enlarge personal and group freedoms. Recognizing the importance of group identity, we shall argue in this section that the ethnic problems that besiege Africa in the recent years are "colonial roots of the contemporary crisis" (Sandbrook 1993, 42).

Apart from the obvious fact that colonialism lumped together heterogeneous people in common territories, it also wakened people's ethnic consciousness, though unintentionally done (Crawford 1982, 75). That is, the idea of basing administrative boundaries and local government on cultural-linguistic lines, as the colonial powers did, fostered ethnicity. A divisive sense of separateness was promoted by the formation of local Native Authorities in British Africa to administer land rights and certain taxes (Sandbrook 1993, 49). For example, it has been argued that one of the major causes of the ethnic clashes experienced in Rwanda-Burundi started immediately after the independence in 1960 when the political elite in these two countries used ethnicity in their struggle for power and state resources. They also used violence as a means of promoting 'ethnic' group consciousness. From the 1970s onwards, each new episode in the history of Hutu-Tutsi violence strengthened the negative perceptions each side [has] of the other (Glynne 1997, 19).

Another important factor worth mentioning was the uneven regional impact of modernization as introduced by colonial rule. Some regions prospered through the development of cash crops, while others did not. Railway construction, for example, contributed to the agricultural development in the areas where the line traversed. Towns and urban employment emerged in the homelands of certain groups, thus favoring their economic advance.

Regardless of the pre-colonial social system, imperialism introduced novel bases of social stratification, of which economic change was a major determinant (Sandbrook 1993, 52-53). Once entrenched in a territory, the colonial power then saw it necessary to exploit whatever economic potentials existed. Each imperial government endeavored to collect enough revenues to cover its expenses and involve at least a few metropolitan companies in lucrative business. Thus, African countries became major mineral and agricultural exporters. In general, cash crops were the main source of revenue in most territories.

Also, the establishment of school in some areas (mostly in the coastal areas) gave some ethnic groups an enviable head-start with western education; thus creating 
a gap between those who benefited from the education and those who were regarded as backward because they did not benefit from the western education. Uneven development therefore brought ethnic consciousness: those holding the advantage struggled to retain it, while the unprivileged one fought for equal share of the cake. And this brought the dichotomous "we-they" mentality which existed during the struggle for independence as well as postcolonial era.

Ethnocentrism in one sense is a purely modern creation and connotation. Sandbrook argues that in the pre-colonial era the sense of shared identity and interest that defines the term was often absent and non-existent (Sandbrook 1982, 51). For example the bitter rivalry between the Kenyan Luo and Kikuyu or the bitter and unfortunate rivalry that exists between the Hutu and Tutsi in Rwanda-Burundi or even between Nanumba and Kokomba in Northern Ghana is severally a twentiethcentury phenomenon. In fact, prior to imperial manipulation, in the case of Kenya, neither constituted a distinct ethnic group. Instead they saw themselves as localized agricultural communities who spoke a mutually intelligible Bantu language and shared common cultural beliefs and practices such as female and male circumcision. The point is that colonial rule fulfilled three conditions which, consciously or unconsciously, fostered tribal consciousness of African people (at least among the Luo and Kikuyu): the cultural-linguistic grid of district administration, uneven development and African political competition. In all, it is noted that despite the many changes that were introduced, post-Independence African bureaucracies continued to function according to the logic of their colonial inheritance.

\section{Neo-Colonialism: Definition, History and Structure}

The most drastic account of domination from abroad on Africa is found in theories of international dependency or, in Africanist vocabulary, neo-colonialism. According to the understanding of this approach, the evolving interests of capital at the core of the global economy is either entirely blocked or permanently subordinated (Rodney 1992, 16.)

On the cause of Africa's position in the global market, the opinions of some political and economic analysts differ. Some writers such as Irving Markovitz argued that Africa's emergent bourgeoisie was a political class that owned its control of economic means to the occupancy of the state office (Markovitz 1997, 45). Others drew attention to the point that dependent states, such as Africa, display weak organisational capacities to confront the developed countries in the global market (Gutkind 1996, 77). 
While some neo-Marxist scholars argue that, upon independence, national development was not the top priority of the African political class, of which the root of underdevelopment could be traced, others content that "development dictatorship" was the political regime that was common in the neo-colonial Africa and therefore responsible for Africa's underdevelopment because with such system development cannot take place (Bratton and Van de Walle1997, 28).

But whatever be the case, it will not be denied that international factors clearly impinge on the formation, consolidation and the development of African states, as intend to argue in this section. Kwame Nkrumah opens the first chapter of his book, Neo-colonialism, by seeing Africa as a paradox that illustrates and highlights neo-colonialism to the core. His argument: "all the products that come from above and below the soil continue to enrich, not Africans predominantly, but groups and individuals who operate to Africa's impoverishment" (Kwame Nkrumah 1970, 1). In using the word "neo-colonialism" then, Nkrumah was actually right when he used it to cover all the activities of the former imperial powers operating in their formal colonies after the independence. And today in Africa, likewise in any other developing countries, new-colonialism even "flourishes as never before." (West Africa Magazine 2002 ,24) This is to say that Western domination over Africa, which is reinforced by international institutions, is as strong as ever. What Nkrumah said as early as 1965 still lives among Africa today? In the introduction to his book, Neo-colonialism, Nkrumah, writes:

The neo-colonialism of today represents imperialism in its final and perhaps its most dangerous state. ...Old-fashioned colonialism is by no means entirely abolished. It still constitutes an African problem, but it is everywhere on the retreat ... In place of colonialism as the main instrument of imperialism we have today neo-colonialism. The essence of neo-colonialism is that the State which is subject to it is, in theory, independent and has all the outward trappings of international sovereignty. [But] in reality its economic system and thus its political policy is directed from outside (Nkrumah 1970, 1).

The institutions that direct Africa's economic system and political policy are referred to by Guy Arnold as "our old friends, the World Bank, the IMF, the WTO, the EU and sometimes the United Nations and the Commonwealth, the International Finance Corporation and the International Development Association" (West Africa Magazine 2002, 24). All these organisations and associations are significantly having US capital as their major backing. Arnold argues that despite the efforts by Africa, the 
former metropolitan powers and USA have managed over the years to fashion these institutions to perpetuate their control over the economically weak countries. These major powers, he argues further, continue manipulating Africa to their ends while "pretending to help the continent overcome its formidable problems" (West Africa Magazine, 2002, 24). Foremost among the countries that constitute neo-colonialists is USA, which many years ago exercised its power in Latin America; other countries are the so-called developed countries.

Neo-colonial powers impose big tariffs on finished goods from Africa, so that it does not survive in the international market. On visiting the cocoa farm at Nankegi in Ghana's Eastern Region on February 2002, Clare Short, the then Tony Blair's Secretary for International Development, told journalists that Paris was "reluctant to remove barriers that impose huge tariffs on finished goods from Africa" (West Africa Magazine 2002, 11). She explained further that although Britain backed the proposal "to remove the barriers, [but] it is a conspiracy from France and the EU to lock Africa into poverty and at the same time Europe preaches free trade" (West Africa Magazine 2002,11 ). The EU, with its common agricultural policy, ensures that outsiders are kept at bay. Agricultural subsidies to countries within the Organisation for Economic Cooperation and Development (including EU member states) amount to $\$ 320$ billion a year, an amount which is roughly the equivalence of the entire gross domestic product of Africa. And on this and others, Short declares that "the world is not in the mood to deal with Africa`s [problems] at the moment" (West Africa Magazine 2002, 11).

Neo-colonialism also takes the form that allows government policies in the neo-colonial state to be secured by payments towards the cost of running the state, by the provision of civil servants in "positions where they can dictate policy, and by monetary control over foreign exchange through the imposition of a banking system controlled by the imperial power (Kwame Nkrumah, 1970). Of all these, the overall result of Neo-colonialism, Nkrumah points out, is that foreign capital will be "used" for exploitation rather than for the development of the less developed parts of the world. Investment under neo-colonialism increases rather than decreases the gap between the rich and the poor countries of the world" (Nkrumah 1970, 239). He proposes that neo-colonial developing world needs to prevent the financial power of the developed countries being used in such a way as to impoverish the less developed ones, because for him, any state that is under neo-colonialism is not the master of its own destiny.

According to Nkrumah, neo-colonialism is the worst form of imperialism, by which hemeans that neo-colonialism for those who practice it, is simply "power without responsibility"; while for those that suffer from it, neo-colonialism means "exploitation 
with redress" (Kwame Nkrumah, 1970). During the old-fashioned colonial era the imperial powers were obliged, at least, to explain and justify their actions at home before taking them abroad for implementation. In the colony people could talk and report back any violent or opposing move made by the colonial representative to the colonial headquarters. In the case of neo-colonialism, no room for such opening was granted. His could also explain why neo-colonialists enjoy postponing social issues that are meant to eliminate the problems of world poverty. Neo-colonialism pretends to be capable of raising the living standards of those to whom it is practised. But the actual fact, as Nkrumah pointed out long ago and at which developing countries still witness, is that the economic object of neo-colonialism "is to keep those standards depressed in the interest of the developed countries" (Nkrumah 1970).

\section{Aid and Trade}

The ultimate purpose of development is to expand the capabilities of people, to increase their ability to live long and healthy lives, to enable them to cultivate their talents and interests, and to afford them an opportunity to live in dignity and with self-respect. The means by which this is achieved may be diverse-by increasing the stock of physical capital, introducing new technologies, changing institutions, altering incentives. Equally important, and sometimes more important, are investments in human capital-the provision of education and training, the creation of employment and opportunities to acquire skills while on the job, the provision of primary health care and adequate nutrition, expenditure on research and on seeking out new sources of information (UNDP, 1990).

During the Cold War, unaligned countries of the Third World were seen as potential allies by both the First and Second World. Therefore, the United States and the Soviet Union went to great lengths to establish connections in these countries by offering economic and military support to gain strategically located alliances (e.g., United States in Vietnam or Soviet Union in Cuba or United Kingdom in Africa). By the end of the Cold War, many Third World countries had adopted capitalist or communist economic models and continued to receive support from the side they had chosen. Throughout the Cold War and beyond, the countries of the Third World have been the priority recipients of Western foreign aid and the focus of economic development through mainstream theories such as modernization theory and dependency theory (Brian and Tomlinson, 2003, 307-321).

By the end of the 1960s, the idea of the Third World came to represent countries in Africa, Asia and Latin America that were considered underdeveloped by the West based on a variety of characteristics (low economic development, low life expectancy, 
high rates of poverty and disease, etc.). (Wolf, and Leslie 1987, 1311-1327). These countries became the targets for aid and support from governments, NGOs and individuals from wealthier nations. One popular model, known as Rostow's Stages of Growth, argued that development takes place in five stages (Traditional Society; Preconditions for Take-off; Take-off; Drive to Maturity; Age of High Mass Consumption) (Rostow 1960). Walt Whitman Rostow argued that Take-off was the critical stage which Africa is missing or struggling with. Thus, foreign aid was needed to help kick start industrialization and economic growth in these countries (W W Rostow, 1960).

However, despite decades of receiving aid and experiencing different development models (which have had very little success), African countries' economies are still dependent on developed countries and are deep in debt. There is now a growing debate about why African countries remain impoverished and underdeveloped after all this time. Many argue that the current methods of aid are not working and are calling for reducing foreign aid (and therefore dependency), by replacing it with trade (Griffin 1991, 65). Historically, development and aid have not accomplished the goals they were meant to and currently the global gap between the rich and poor is greater than ever (Sandbrook 1982, 42-43).

Talking about the world economy, the Group of Eight plays an important role. Although the Group of Eight (G-8) can hardly be described as an institution of international governance, the G-8 is the closest thing we have at present to a forum where global economic issues are discussed and policies agreed. This clearly is unsatisfactory. The G-8 is a club of rich countries representing a minority of the world's population. It has no authority or indeed inclination to speak for the rest of the world or take their interests into account.

Compounding the problem of absent or ineffective international institutions are structural features of the world economy that inhibit "trickle down" processes of human betterment. First, there is the high degree of international inequality in the distribution of income. Second, there are enormous differences in the technology available to rich countries and poor countries. Third, there is the relative lack of mobility of labour internationally as compared to the much higher degree of mobility nationally. Thus low income labour is unable to migrate readily from poor countries to rich and thereby ensure, on a global level, that the returns to equivalent skills and efforts are equalized. Fourth, there is at best only a weak tendency for capital to move from rich countries to poor. Most capital movements are from one rich country to another and thus do nothing to spread the benefits of growth to the lowest income people in the lowest income countries. Official development assistance between 1960 and 1985 varied between 1.9 percent of the GDP of developing countries in 1961 and 
1962 and 0.8 per cent in 1985 . Never of great significance to the developing world, the flow of foreign aid relative to the self-generated resources of developing countries has declined slowly but steadily for over a quarter of a century and is likely to continue to fall for the foreseeable future. Indeed one consequence of the end of the Cold War may be an accelerated decline in aid (Griffin, 1991).

In principle foreign aid could be a major source of capital, fuelling the growth of developing countries and helping to promote human development. Aid in practice however has failed to live up to the expectations of its advocates and disillusionment now is widespread. It is impossible to demonstrate statistically that foreign aid programmes as actually administered have had a positive effect on growth. Nor can one demonstrate that aid has been distributed equitably, the largest amounts per capita going to the poorest countries. Within countries, it cannot be demonstrated that most of the aid had been of direct benefit to poor people. Thus the connection between foreign aid and the human development of poor people is at best tenuous.

Some foreign aid has of course made a net addition to the stock of capital in developing countries and some has added to human capital and thereby contributed to human development. But the evidence now is clear that much foreign aid, once all direct and indirect effects are taken into account, has resulted in an increase in unproductive consumption, the amassing of monetary reserves and capital flight and perhaps in a decline in the productivity of investment. If long term foreign assistance intended to alleviate poverty and promote human and economic development is to have an honourable future, major reforms in how it is provided and used will be necessary.

The most important issue linking human development and international capital revolves around the role of foreign aid. Foreign aid includes the highly concessional loans and outright grants to developing countries from the Organisation for Economic Co-operation and Development (OECD) and other rich countries, channeled both bilaterally and through multilateral development agencies such as the World Bank and the Regional Development Banks. It is often taken for granted that foreign assistance actually assists developing countries. Often, this is not the case. The Committee for Development Planning reflects an emerging consensus when it states that far too much aid serves no developmental purpose but is used instead to promote the exports of the donor country, to encourage the use of (imported) capital-intensive methods of production or to strengthen the police and armed forces of the recipient country (The Committee of Development Planning 1990, 38).

Of serious consequence is that if genuine loan is given, the obvious high rate 
that is attached to it makes it become another form of neo-colonialism. This was evident when donor countries threaten to cut aids to Africa if homosexuality is not legalised. Reacting to the threat by the United Kingdom to cut aid to Ghana if the country failed to recognise the gay right, former president of Ghana, John Atta Mills said the UK could not impose its values on Ghana because homosexuality is against the religious and cultural values of Ghana and he would never legalise homosexuality. Uganda also rejected the threat, with an official accusing the UK of showing a bullying mentality. Reacting to a comment quoted from The Wall Street Journal that, even if genuine aid is given, the underdeveloped world has no potential to develop and this would be like "pouring money down a bottomless well, weakening the donor nations without effectively curing the ills of the recipients", Nkrumah replied that the argument is true in the sense that the less developed world "will not become developed through the goodwill or generosity of the developed powers. It can only become developed through a struggle against the external forces which have a vested interest in keeping it undeveloped" (Nkrumah 1970).

The whole story of 'aid' is aptly more than what it might seem to be, for there is other conditions which hedge around it. These financial institutions have the habit of forcing would-be borrowers to submit to various offensive conditions. These conditions include supplying information about their economies and submitting their policies and plans to be reviewed by the World Bank; accepting agency supervision of their use of aid or loans; the conclusion of commerce and navigation treaties; agreements for economic co-operation; the right to meddle in internal finances, including currency and foreign exchange; to lower trade barriers in favour of the donor country's goods and capital; to protect the interests of private investments; determination of how the fund are to be used; forcing the recipient to set up counterpart funds; to supply raw materials to the donor countries; the use of the majority of such funds to buy goods from the donor nation or use the funds to award contract to the donor nation, and many other conditions (Nkrumah 1970, 243).

Significantly, the only type of 'aid' which the neo-colonial masters consider as safe and therefore willing to give is what Nkrumah referred to as "military aid." According to him, economically advanced countries become generous only, and only, when the less developed countries are brought to a state of economic chaos and misery. The 'aids' given will be monitored so that they are 'properly' utilized destruction of neo-colonial State-Africa. Concretized in African context today, practically all the territories that are presently fighting have the support of neo-colonial powers, directly or indirectly. The bitter truth here is that the neo-colonial masters are creating market for their products by artificially creating war. This means that the absence of war will result in low supply of weapons and drugs, thereby affecting the suppliers' economy. 
Indeed it has been estimated that the retail value of trade in illegal drugs exceeds international trade in oil and is second only to the weapons trade (LaMond 1991, 3).

A report by the Campaign against the Arms Trade reveals in 1999 that African countries received arms worth $£ 52$ million in deals with various British firms, and that this figure was more double in 2000 with $£ 125.5$ million deal; the figure continues to increase and it is expected to top extensively in the few years ahead (West Africa Magazine 2002, 25). So what is given as 'aid' is not but a way of promoting their market. Or, as it has been argued that the supplying of ammunitions and drugs to Africa is another way of exploiting the continent of its rich mineral resource: the supply of weapon to RUF in Sierra Leone, for example, would be exchanged with diamond; the same thing applied to UNITA in Angola, which had greatly enjoyed the support of USA to fight against the former Marxist-Leninist regime, and host of many countries in Africa today (Sandbrook 1995, 101). As one economist remarks: "it is pleasant to feel that you are helping your neigbours, and at the same time increasing your own profits" (Benharm 1991, 56). It is worthwhile to note that the technique used by the foreign power is to supply "money, aircraft, military equipment of all kinds, and the strategic and tactical command from General Staff down to officer 'advisers', while the troops of the puppet government bear the brunt of the fighting" (Nkrumah 1970, 243).

While agreeing that much aid in the past has been wasted, there is evidence that when donor and recipient act responsibly, foreign aid can indeed be of benefit. The first thing that needs to be done is to depoliticize aid by bringing it under the control of a supranational authority operating under clearly defined and agreed principles. These principles should include both the mobilization and allocation of aid funds. It may be too much to expect that the leading donor countries would agree to channel all foreign assistance through a supranational authority, but it should be possible to reach agreement to channel most foreign aid through such an authority while leaving individual countries free to supplement multilateral assistance with bilateral programmes if they wish to do so. This would not be a radical departure from present practice although it would change the balance decisively in favour of multilateral assistance. By and large, Africa, through its African Union (AU) should learn how to be "able to resist unfavourable term imposed by WTO, offer information and support to individual countries as well as initiate development” (Daily Graphic, 2002, 7).

\section{Monopoly and Privatization}

The emergence of neo-colonialism in Africa brings about the emergence of monopolies and the consequent limitation in free enterprise competition associated 
with pre-monopoly capitalism. The monopolies that dominate the economy of the neo-colonial societies of Africa are basically foreign multinational companies. They are usually giant enterprises which operate in various countries and produce various complementary products at the same time (Okwudiba 1996, 67). Notable among the companies, operating in Nigeria for example, are Gold oil, Mobil oil, Shell oil, Dumez, Julius Berger Construction Company, Sanyo Electronics, Peugeot Automobile, Pfizer, etc. With this consideration, it is argued, Africa contributes greatly to the development of Western countries through the profits that are made in Africa by these multinational companies and then repatriate to Europe to create new enterprises, jobs etc, thus leading to development (Okwudiba 1996, 68).

Also the advanced capitalist nations ensure that most of "the trade of the African countries are with them, that the major adversary of these countries, the communist powers, share very minimally in this trade, that the aid and monetary transactions of African countries are with the advanced western powers, that the ethnic, rules, regulations and procedure for the conduct of business activities follow the lines laid down during the colonial era and which favour the West" (Okwudiba 1996, 67-68). At last, it is obvious that African countries find it extremely difficult to escape being within the western camp in the global struggle between the opposing social systems. Rating it to his vision on African unity, Nkrumah contends that the developing small states need to combine efforts together otherwise they will "be compelled to sell their primary products at prices dictated by the developed nations and buy their manufactured goods at the prices fixed by them (Nkrumah 1970). He argues further that as long as the neo-colonialism can prevent political and economic conditions for optimum development, the Third World countries, either under neocolonialist control or not, will not be able to create a large enough market to support industrialization. More so, they will lack the financial capacity to force the developed countries to accept their primary product at a fair price.

The pressures upon African countries to conform to economic criteria set by the West continue unabated. Such conditions such as that Africa "must privatize to qualify for aid; they must improve their human right record; they must allow Western organizations to monitor their elections; they must be democratic in the Western multiparty tradition" (West Africa Magazine 2002, 24). The West insists upon these conditions as though only calamity must be the alternative; and yet throughout the now almost forgotten Cold War such conditionalities were rarely mentioned and never enforced. Tanzania has, for example, has almost privatized its 400 parastatal corporations, with the result that outside investors are beginning to return and the country "has become the blue-eyed boy of the IMF" (West Africa Magazine 2002, 24). 
Okwudiba deals with one of the most preferred instruments of state economic policy in the sixties, seventies, and eighties, which are state owned enterprises (Okwudiba 1999). Basing his focus on the countries of Kenya, Uganda and Tanzania in East Africa, Okwudiba traces the origins of state enterprises in East Africa to the colonial period, and the colonial state. The sector underwent tremendous expansion after independence. Reasons for this expansion are many and varied including economic nationalism, ideology, and capital cost minimisation for transitional corporations. A review of their performance reveals a mixed picture with many of them experiencing serious structural, managerial and operational problems. Together with Asfaw Kimssa, they both agree that solutions to most of the problems including privatization have not been easy to implement. Kimssa goes further to say that privatization will cause denationalization of the African economies, excessive capital outflows, high unemployment and increasing inequality and justice (Kimssa 1999, 66).

Mamadou Dia echoes the observations of the World Bank study on adjustment in Africa, which claim that adjustment supported policy reforms in African countries have generally been more successful in improving their macroeconomics that their public and financial sectors. He goes on to argue that "the social, economic and political crisis of post independence sub-Saharan Africa can be largely attributed to a crisis of institutions, resulting from a structural disconnect between the indigenous institutions and management practices characterizing civil society, and modern institutions and governance" (Mamadou, 1999, 66). He argues further that this disconnection has created a "crisis of legitimacy and accountability that affect governance and the performance of public administration, as well as the development of an indigenous private sector and African entrepreneurship" (Mamadou, 1999, 67). It could be added that recognizing Africa's crisis as one of institutions, demands changes on all fronts. Indigenous institutions must be willing to initiate change and move away from conservatism toward innovation.

\section{Globalization}

There is scarcely anybody in Africa who would talk of the last 300 years, including the periods from 1957 when Ghana for instance gained independence, in language flattering either to colonialism or to governments that have taken over power since political independence. World Bank and IMF officials who see wrong only in the policies of African governments choose to forget that their own fingers have written the various documents on which these policies-from important substitution to now export orientation-were based. It is also a measure of their intellectual dishonesty, or ideological brainwashing, says Yash Tandon, that they cannot see the connection between globalisation and Africa's poverty (Yash, 1999, 9). 
For example, much of the discussion about the scourge of HIV/AIDS in Africa was centred on the availability of anti-retroviral drugs. These drugs were prohibitively expensive for most Africans if purchased from the major Northern pharmaceutical companies, but might be cheaper if imported from India or Brazil. But whether expensive or cheap-that is, whether life or death determinative for Africansdepended in our globalised world of today on the policies and decisions of the World Trade Organization and it's most powerful member states, which, of course, are the headquarters of the major pharmaceutical industries. "Globalization" is one of the most widely used and least clearly defined of the terms in political and economic discourses today.

We shall use the term "globalization" to refer to the phenomenon of increasing integration of nation states through economic exchanges, political configurations, technological advances and cultural influences, which are the integrating factors of globalisation today.

Economic exchange includes cross-border trade in goods and services, capital flows and financial investments. Today almost three trillion US dollars moves around the world every day, seeking not the best production but the best return on speculation. Of the one hundred largest economic entities in the world, fifty of them are nation states and fifty are transitional corporations (CAFOD Briefing Paper, December 2000, 15).

Political configurations are the new or renewed structures of the United Nations, the World Bank, the International Monetary Fund, the World Trade Organisation, the blocs of the European Community, the North American Free Trade Area, etc. These are not democratically elected governments but have considerably more power than any such governments. For example, the expanded "trade related" mandate of the WTO now touches areas like intellectual property, employment policies, environmental regulations, etc.

Technological advances include the rapidly growing utilization of electronic communications (phone, internet-e-mail, Facebook, Twitter, Viber, WhatsApp, etc) and the increasing ease of transportation. We live in an information age, we live in a "borderless age," we live in a very fast age.

Cultural influences are obvious in the "westernization" of so much of popular future in music, clothes, life styles, etc. As of 2005, the single largest export industry for the United States in not aircrafts, automobiles, computers, but entertainmentHollywood films and television programmes (UNDP, 2006, 33). 
The structures that are the foundations of globalisation as we experience it today, and that guide its future development, are important to identify. Here let us speak of only a few of the more important structures and then identify their impact on Africa.

Globalization as currently experienced is, in its major direction, an incarnation of neo-liberalism (Latin American Provincials of the Society of Jesus 2007, 281). In its extreme, this ideology is a kind of "economic fundamentalism" that puts an absolute value on the operation of the market and subordinate people's lives, the function of society, the policies of government and the role of the state to this unrestricted free market. Neo-liberal policies support economic growth as an end in itself and use macro-economic indicators as the primary measurements of a healthy society. It assumes almost a religious character, as greed becomes a virtue, competition a commandment, and profit a sign of salvation. Dissenters are dismissed as nonbelievers at best, and heretics at worst. Problems with the operation of this ideologyeven such massive problems as the collapses experienced a few years ago in Asian economies-are seen not as "mortal sins" but as mere "falls from grace" that deserve more penitential practice of the exercises that are demanded by the ideology (Mihevc, 2005, 21-42).

Even before trade in basic goods and services, by far the largest component of globalization is the movement of money across borders. This is disconnected capital, institutionally managed money that moves with the speed of a mouse click on a computer, putting money into a situation for quick return, pulling it out equally speedily for a safe return. The severe problems experienced by the "Asian Tigers" were largely due to the rapid and uncontrolled movement of capital (Mihevc, 2005, 21-42).

Trade is usually under the guidance of the creed of "free trade." Because of the technological advances in communications and transportation, goods produced in one country move rapidly into other countries, frequently disrupting traditional productive patterns in the second country. One can think simply of the decline in the automobile industry in the United States because of the competition from Japan and China. Trade relationships may be "free" but whether or not they are "fair" depends on factors of power, size, experience, skills, etc. And in our world of today, these factors are very a-symmetrical.

We all have heard of, indeed, experienced, "cultural imperialism," the imposition of values and styles of life by dominant forces. One commentator has referred to the contemporary process of globalization as the birth of the "McWorld" - a cultural integration of fast music (MTV), fast computers (MacIntosh) and fast food (McDonald's) (Benjamin Barber, 2012, 24). Cultural imperialism is not a 
new phenomenon, but it assumes alarming proportions when driven by the new technologies and profit propensities of the dynamics of globalization. A Jesuit economist, Xabier Gorostiaga, refers to the "predominance of geo-culture over the geo-political and the geo-economic" (Xabier 2006, 9). Traditional cultural values such as family, community, respect for life, hospitality, etc., come into strong confrontation and do losing battle with the values communicated through Western music, movies, videos, cable and satellite television, advertisements, and the idolized figures of entertainment and sports.

With the end of the Cold War, there has been a significant change in the geopolitical structures shaped by the East-West conflict. A bi-polar world has given way to a design for a "New World Order." But the political dimensions of this new order are themselves subject to the economic influences of available markets, accessible resources, and technological arrangements etc. The point made several years ago by Pope John XXXIII, that development of global economic relationships has outstripped the development of political governance structures to promote the global common good, (Pope John XXXIII 1963, 135-136) is more than ever true today.

We may be familiar with the expression, the "champagne glass economy," a picture of the globe emerging from the UNDP Human Development Reports that the richest $20 \%$ of the world's population receives $86 \%$ of global income, while the poorest $20 \%$ receives just $1 \%$. (UNDP 2006, 3). This is a picture of the globe in which the huge majority occupies only the narrowest stem of the glass while the tiny rich minority enjoys the broad bowel of affluence. In this champagne glass, we all know where the majority of Africans fit! The assets of the three richest people are more than the combined GNP of all the least developed countries; the assets of the 200 richest people are more than the combined income of $41 \%$ of the world's people; a yearly contribution of $1 \%$ of the wealth of the 200 richest people could provide universal access to primary education for all (UNDP 2006, 38). Is globalization then good for Africa's future? Not in its present form that has been exaggerating the gap between Africa and the so-called developed world.

Second, the current structuring of globalisation creates an increasing marginalization of Africa in the very process of integrating it into the global economy. For there is a stark disparity between rich and poor in the global opportunities offered in trade, investment and technologies. This marginalization has increased dramatically in recent past, and shows no signs of decreasing. As the UNDP 2006 Report commented:

Some have predicted convergence. Yet the past decade has shown increasing concentration of income, resources and wealth among people, corporations and countries.... 
All these trends are not the inevitable consequences of global economic integration - but they have run ahead of global governance to share the benefits (UNDP 2006, 3).

A third observation deals with the growing environmental threat to Africa. This comes from a particularly disturbing aspect of globalization, the phenomenon of global warming. As it were, this phenomenon is caused mostly by carbon dioxide emissions from automobiles, power plants and industries that are, of course, most heavily concentrated in the so-called developed countries. Most pollution in the world is caused by economic activities in the developed countries, (Walley 2001, 182.) but the developing countries can be expected increasingly to add to the problem as their economies become ever more industrialized and urbanized and as their agriculture comes to rely more and more on chemical based technologies. Greater consciousness in rich countries of the hazards to health of some industrial processes and greater concern about the deterioration of the environment have led them to impose relatively strict health, safely, waste disposal and environmental regulations. One response has been an attempt to shift to poor countries the costs of industrialization in the rich ones. Examples include efforts to dispose of contaminated nuclear waste in developing countries, shipments of urban generated garbage to developing countries (such as the chemical factory that exploded and caused death, blindness and intense suffering in Bhopal, India). While it would be wrong to oppose transfers of economic activities from rich countries to poor, or to impose identical health, safety and environmental standards worldwide, it would be equally wrong to condone an economic system under which what is unacceptable in the back yards of the rich is dumped unceremoniously in the front yards of the poor.

According to the United Nations Environmental Programme, the effects and impacts of global warming in Africa is frightening, with the rising levels of disease, famine and poverty.

According to Inter-governmental Panel on Climate Change (IPCC) global warming will condemn millions to hunger as crops decline in Asia and Africa. Prof. Robert Winston, one time World Bank Chief Scientist and Chairman of IPCC, noted that the earth is getting warmer than at any other time during the last 10,000 years. He echoed that global warming is now the greatest threat to mankind, but singled out Africa as the lowest rate of emissions. But then, "sub-Saharan Africa, along with low-lying small Island states in the Indian and Pacific Oceans, are the most vulnerable to climate change because widespread poverty limits their capabilities to adapt to a continuing changing climate" (West Africa magazine 2001, 11). We have had clear proof of that with the former USA president, President George Bush's blunt rejection 
of the Kyoto Protocol agreements to limit harmful emissions. Reports show that USA is the highest pollution of the environment (West Africa magazine 2001, 11).

But as unsuccessful globalisation might appear to be in Africa, however, it could still work perfectly and be of benefit to Africa if it is modified. On this ground, Peter J. Henriot, suggests what he calls Alternatives to Globalisation. (Peter J. Henriot, Edward P. DeBerri, and Michael J. Schulthesis, 1992).To this, Peter Henriot suggests a three-fold path globalisation of solidarity, globalisation of concern and globalisation from below.

\section{Modernization and Dependency Theories}

Modernisation and dependency are theories which specify the concept of development. These theories reveal valid explanations for both development and underdevelopment of developed and developing countries. According to Matunhu, modernisation is about Africa following the developmental footsteps of Europe (largely the former coloniser of Africa) (Matunhu 2011, 65-72). He expounds that, according to modernity, policies intended to raise the standard of living of the poor often consist of disseminating knowledge and information about more efficient techniques of production. On his part, Mar defines modernisation as a process of transforming from traditional or underdeveloped society to a modern western societies way of life (M. S. Mar, 2008). From the definitions, modernisation is a developmental process which was derived from the steps followed by western countries when they were doing their development.

As a compliment to modernisation is dependency. Dependency is a historical condition which shapes a certain structure of the world economy such that it favours some countries to the detriment of others and limits the development possibilities of the subordinate economics so much that it presents a situation in which the economy of a certain group of countries is conditioned by the development and expansion of another economy (Ferraro 2008). From the definition, dependency theory attempts to explain the present underdeveloped state of many nations in the world by examining the patterns of interactions among nations and by arguing that inequality among nations is an intrinsic part of those interactions. In this respect, it is possible to refer to Modernization theory and Dependency theory which, being quite different, still have certain similarities in their views on the modern world and relationships between developed and developing countries. Also they aim to explain development but using different angles.

Modernization theorist Rostow reveals that, modernization theory has five major stages that a traditional society has to pass through to become a modern society. 
In this theory it is assumed that all countries pass through these stages in order for them to reach a stage of being developed. Therefore, the Rostowian theory (named after its inventor, Walt Whitman Rostow) identifies these five stages which the less developed has to follow.

Firstly it is the Primitive Society Stage which is characterised by subsistence farming and barter trade. The Second is the Preparation for Take-off which is characterised by specialization, production of surplus goods and trade. Transport infrastructure is developed to support trade. In addition the stage encourages savings and investment. The third state is the Take-off Stage where industrialization increases and the economy switches from agriculture to manufacturing. The fourth stage is regarded as the Drive to Maturity where the economy diversifies into new areas and there is less reliance on imports. And the last stage is Period of Mass Consumption where the economy gears on mass production and service sector becomes increasingly dominating. In general, modernization led to the introduction of hybrids, the green house technology, genetically modified (GMO) food, use of artificial fertilizers, insecticides, tractors and the application of other scientific knowledge to replace traditional agricultural practices (Matunhu 2011, 66)

According to Sharmila dependency theory is the relationship between two or more countries assumes the form of independence when some (dominant ones) can do this as reflection of the expansion. Therefore the relationship between these countries is not equal. The dependency theory views developing countries as is politically conservative because they view developing countries as undeveloped because they lack the qualities that developed nations have. Moreover dependency theory states that, there is the core, semi periphery and the periphery. The core consists of developed countries, semi periphery is the newly industrialized countries like Brazil and the peripheries are developing countries (Sharmila 2008, 34).

Dos Santos as well as Rodney agree that since dependency assumes that development depends on the relationship between center and the periphery where the center or the core are the first world and developed nations while the periphery refers to the third world and developing states, dependent states, therefore, should attempt to pursue policies of self-reliance to avoid unfair relationship between the periphery and core. This is based on the argument that, Africa deprived by Europe of political and economic decision power, and lacking sustained investment funds, trod the reverse path, and then sinking deeper and deeper into non development and poverty (Matunhu 2011, 66).

As Matunhu reveals, Modernization impoverished Africa through colonialism and imperialism by the West and this trend is with us today as the East takes its turn 
to deplete the continent's resources such as oil and minerals. Africa needs to outgrow poverty and underdevelopment but this, according to him, may not be possible as long as we still believe in the power and strength of modernity at the expense of promoting new theories for Africa's development (Matunhu 2011, 70). Modernization and Dependency theory stand on the ground that Western countries are the world leaders due to their higher level of development, which affects practically all spheres of life, including economic, political, social, and even cultural life. As a result, there exist a strong link between developed and developing countries. This may be true in the sense that, the modernisation theory mentions the development gap between developing and undeveloped countries by revealing that, developing countries must go through various stages to reach fifth stage of high consumption where the developed countries are found. Also dependency theory reveals the gap by postulating that, there are developing countries which are found at the periphery and developed countries at the core. This clearly shows that both theories acknowledge a development gap between developing and developed countries (Matunhu 2011, 70).

Both Modernization and Dependency theories underline that the relationships between developed and developing countries is unequal and there exists a kind of dependence of developing countries on developed ones. Also, both theories underline the dominant position of Western countries in the modern world and leave little room for the alternative ways of the development but the western one, which is viewed as the only way of the development of the future world in the context of the global economy. It is worthy of mention that both theories are ethnocentric in a way because they practically ignore the possibility of the alternative development of developing countries but, instead they insist that the development of western countries will still be on top! (Matunhu 2011).

So, poverty in the Third World is not 'traditional' or accidental. It is a necessary companion to the richness of the developed world. The expansion of the industrial world deformed the rest of the world. Joshi Sharmila, historian Eric Williams, for example, argues that the slave trade between Africa and the Caribbean islands was responsible for the emergence of a commercial middle class in Britain and eventually for Britain's industrial revolution. Slaves were taken from Africa to the Caribbean; their unpaid and coerced labour produced such profitable commodities as sugar or cotton, which were taken to Europe for huge profits. This provided the conditions for 'take-off' for Britain's industrial revolution (Sharmila 2008, 40).

These examples show the dependency approach: the actual creation of underdevelopment at the cost of development. West African societies were uprooted by centuries of the slave trade; in the Caribbean the plantation system (set up to meet 
the needs of the colonists) met no local needs and impoverished workers. Mines in the Third World produced bauxite, tin, iron and other metals and minerals for the industries of the West. All of this depended on cheap indentured or slave labour. Many of the regions of the world were left with skewed, impoverished economies and devastated populations while the now-developed countries gained prosperity.

Matunhu, Ellis and Biggs suggest that underdeveloped states need to design policies which are meant to raise the standard of living of the poor which consist of disseminating knowledge and information about more efficient techniques of production. Modernisation agriculture process which includes encouraging farmers to try new crops, new production methods and new marketing skills be viewed as a good example. This is because modernisation is about exchanging of older agriculture practices with something more recent (Sharmila 2008, 85).

Poverty reduction policies and strategies have tended to be influenced by the theories of development. Modernistic polices and strategies tend to be top-down in approach. They see development of Africa as the responsibility of the metropolitan states. Thus, development strategies and finances are produced, packaged and sent to Africa by the economically powerful states. The beneficiaries of development support are usually marginalised. The dependency theory attributes rural poverty to the continuous pillage of human and nonhuman resources from the satellite to the metropolis. The same pattern is discernable between the modern and the traditional communities. The underdevelopment of Africa is indeed a result of cultural collision between two different development spheres - the West and Africa. The former, because of its strategic and technological advantage over Africa, it was able to choke and subdue Africa's culture and value system. In the process, Africa lost its right to determine its way to development. To develop, then, Africa needs to detach itself from the western mentality of modernisation and dependency. Thinking that, by destiny, Africa is designed to perpetually depend on the West for survival (dependency), and that if it must develop at all, it must follow the western style of development (modernisation).

\section{Conclusion}

As a parenthetical conclusion, there is the need to reaffirm that Africa has experienced four stages of outside penetration on the continent by forces which have had negative social consequences on the African people's integral development. This outside penetration has occurred over the past five hundred years as argued: Firstly, as slavery, during which the continent's most precious resources, African women and men were stolen away by global traders for the benefits of Arab, European 
and American countries. Secondly, as colonialism, when British, French, Belgium, Portuguese, Italian and German interests dictated the way that map-boundaries were drawn, transportation and communication lines were established, agricultural and mineral resources were exploited, and religious and cultural patterns were introduced.

Thirdly, as neo-colonialism, the form taken by outside political pressures and economic forces that set trade patterns, investment policies, debt arrangements, technology introductions, political alliances, etc. Fourthly, as globalization characterized by the attachment and integration of the economies of the world through trade and financial flows, technology and information exchanges, and the movement of people.

On the forefront are the issues of modernization and dependency. Modernization advocates that if Africa must develop it must follow the pattern of the developed world. In other words, if the developed world did A, B, C, D, to succeed, Africa too must follow suit by doing the same A, B, C, D. But this theory forgets that Africa is a unique entity with unique characteristics. Meaning that what works for the Western world may not necessarily work for Africa. Dependence theory thinks that the perennial poverty in Africa is as a result of her continual dependence on the Western world for survival. The Western world would also want this to continue because the advancement of Africa means economic imbalance in the developed world. This historical situation dates back to the slave trade, and still living among Africa up to this moment. But the identification of these problems does not mean that Africa in general does not contribute to her problems. This article however serves as a sequel for studies into the internal forces against Africa's democracy and development.

\section{References}

A. L. Adu, and Rwekaza Mukandala 1999. “The Colonial Legacy,” African Public Administration, Nairobi: Oxford University Press.

Barber, Benjamin. 2012. "Jihad vs McWorld," The Atlantic Monthly.

Benharm, Courteney. 1991. Economic Aid to Under-developed Countries. London: Oxford University Press.

Bratton Michael and Nocolas van de Walle. 1997. Democratic Experiments in Africa. New York: Cambridge University Press.

Brian,Roger. and Tomlinson, B.R. 2003. "What was the Third World”, Journal of Contemporary History, 38(2): 307-321.

Crawford, Young. 1982 “Patterns of Social Conflict: State, Class and Ethnicity”, Daedalus, 110, 2. 


\section{E. Brenya \& S. Adu-Gyamfi}

Daily Graphic, “The New Political Dawn”, March 5, 2002.

Ferraro, Vittoria. 2008. Dependency Theory: An Introduction.

Glynne, Evans. 1997. Responding to Crises in the African Great Lakes. Nairobi: Oxford University Press.

Griffin, Keith. 1991. Foreign Aid After the Cold War. Chicago: Oxford Press.

Gutkind, Peter C. 1996. The Political Economy of Contemporary Africa. London: Sage Press.

Henriot, Peter J. Edward P. DeBerri, and Michael J. Schulthesis. 1992. Catholic Social Teaching: Our Best Kept Secret. New York: Orbis Books.

Henriot, Peter J.1997. "Retreat of the State: Political Consequences with Social Implications for Zambia," Jesuit Centre for Theological Reflection, unpublished article, p. 39-60.

Hollenbach, David. 2000 “Working for Solidarity in an Age of Globalisation," Jesuit Centre for Theological Reflection, unpublished article.

Kimssa, Asfaw. and Rwekaza. 1999. "State Owned Enterprises," African Public Administration, Nairobi: Oxford University Press.

L. Mair, 1990. Primitive Governance. Baltimore: Penguin Books.

LaMond, Tullis. 1991. Handbook of Research on the Illicit Drug Traffic: Socio-economic and Political Consequences. Westport: Greenwood Press.

M. S. Mar, 2008. Modernistaion Vs Dependence Theory.

Mamadou, Dia. and Rwekaza Mukandala. 1999. "Crisis In Contemporary Africa Public Administration," African Public Administration, Nairobi: Oxford University Press.

Markovitz, Irving L. 1997. Power and Class in Africa. Englewood Cliffs: Prentice-Hall.

Matunhu, Jephias. 2011. A Critique Of Modernization And Dependency Theories In Africa: Critical Assessment: Midlands State University Zimbabwe, African Journal of History and Culture, pp. 65-72.

Mihevc, John. 2005. The Market Tells Them So: The World Bank and Economic Fundamentalism in Africa. Penang: Third World Network, pp. 21-42.

Mitelman, James H. 1991. "The End of a Millennium Changing Structures of World order and the Challenges of Globalisation", Political Economy and Foreign Policy in the Third World in the 1990s, unpublished note: Halifax, Nova Scotia.

Nkrumah, Kwame. 1970. Neo-Colonialism: The Last Stage of Imperialism, Ibadan: Heinemann Educational Books Ltd. 
Nyerere, Julius K. 1980. Ujamaa: Essays on Socialism. Dar es Salaam: Oxford University Press.

Okwudiba Nnoli. 1996. Introduction to Politics. Ikeja: Longman Group.

Okwudiba, Nnoli. and Rwekaza Mukandala, 1999. "State owned Enterprises," African Public Administration, Nairobi: Oxford University Press.

Pistol in Henry IV, pt. 2, Act V, Scene 3. In A. G. Hopkins, "Of Africa and Golden Joys" in Geneva Africa (1985), XXIII, I: p. 27.

Pope John XXXIII, 1963. Peace on Earth, Rome: Vatican Press, pp. 135-136.

Rostow, W W. 1960. The Stages of Economic Growth.

Sandbrook, Richard. 1993. The Politics of Africa's Economic Stagnation. New York: Cambridge University Press.

Sandbrook, Richard. 1982. The Politics of Basic Needs: Urban Aspects of Assaulting Poverty in Africa. London: Heinermann.

Sharmila, Joshi. 2008. Theories of Development vs Dependency.

The Committee of Development Planning, Regional Trading Blocs: A Threat to the Multilateral Trading System? United Nations, New York.

“The Rough Guide to Globalisation.” 2000. CAFOD Briefing Paper.

United Nations Development Programme, Human Development Report 2006. URL: http:// www.palgrave.com/page/detail/human-development-report-2006-united-nationsdevelopment-programme/?isb=9780230500587

United Nations Environmental Programme. 2001. “Global Warming: Africa Hit hardest,” Press release by Intergovernmental Panel on Climate Change (IPCC), Nairobi.

Walter. Rodney, 1992. How Europe Underdeveloped Africa, Dar es Salaam: Tanzania Publishing House West Africa Magazine, 2002. "Neo-colonialism: Alive and Flourishing."

West Africa. 2002. “The Banana Question.”

Wickens, Peter. 1981. An Economic History of Africa, Cape Town: Oxford University Press.

Wogaman, J. Philip Christian. 2000. Perspective on Politics Louisville: Westminster John Knox Press.

Wolf-Phillips, Leslie. 1987. "Why 'Third World’?: Origin, Definition and Usage”, Third World Quarterly, 9(4): 1311-1327.

World Bank, World Development Report 2006/2007: Attacking Poverty Oxford: Oxford University Press. 


\section{E. Brenya \& S. Adu-Gyamfi}

World Bank, World Development Report. 1991. Washington DC.

Wwalley, J. 2001. “The Interface Between Environmental and Trade Policies, Economic Journal.

Xabier, Gorostiaga. 2006. “Citizens of the Planet and of the 21st Century," SEDOS Bulletin, vol. 28, no. 3.

Yash, Tandon. 1999. Globalisation: Africa’s Options ISGN Monograph. No 2, Queen City, Philippines: International South Group Network. 